\title{
KLKB1 Gene
}

National Cancer Institute

\section{Source}

National Cancer Institute. KLKB1 Gene. NCI Thesaurus. Code C95565.

This gene plays a role in proteolytic processing. 